\title{
Analysis of the functional state of students in the process of healthy training exercises in different phases of the ovarian-menstrual cycle
}

\author{
Petrenko N.V., Petrenko O.P., Romanova V.B., Ostapenko V.V. \\ Sumy State University, Ukraine
}

\begin{abstract}
Purpose:

to substantiate the application of a rational program of health-training sessions in the educational process of physical education of students in different phases of the ovarian-menstrual cycle.

Material: $\quad$ in study participated students $(n=127)$, who did not have deviations in health (the main medical group). According to the results of the tests were determined: heart rate; blood pressure; vital capacity of the lungs. To determine physical performance was used Harvard step-test. Physical exercises from the main means of health fitness were used differentially and dosed.

Results: It was established that the consideration in the phases of the ovarian-menstrual cycle of indicators of the functional state, changes in well-being and working capacity give an opportunity: planning loads in the training process; adjustment of volume and intensity of loads. We recommend to schedule the load of our program as follows: in the menstrual phase - the development of flexibility (moderate load); in the postmenstrual phase - development of coordination, overall endurance; in ovulatory - speed development; in postovulatory - development of special endurance; in premenstrual - the development of strength, flexibility. In the postmenstrual and postovulatory phase, a high level of physical working capacity, functional state of the cardiopulmonary system has been registered. It also has a positive effect on body weight correction in the women students.

Conclusions: When developing programs of health training sessions with women students it is necessary to take into account the phases of the ovarian-menstrual cycle.

Keywords: $\quad \begin{aligned} & \text { account the phases of the ovarian-menstrual cycle. } \\ & \text { physical education, functional state, health training sessions, students, ovarian-menstrual cycle. }\end{aligned}$
\end{abstract}

\section{Introduction}

The process of physical education of student youth attracts the attention of many specialists in the field of physical culture and sports. In recent years, significant changes have been made both in physical education disciplines and in the methods of teaching them $[5,8$, 13, 31]. Particular attention deserves physical education of students. For the correction of the functional state of students exist a large number of authoring techniques using various means of recreational physical culture [6, $8,9,32]$.

It was considered the approaches to the organization of the training process of women. They were based on the differentiation of volume, intensity and direction of training loads in accordance with the functional capabilities of the organism in different phases of the ovarian-menstrual cycle (OMC) [7].

It was developed an author's program of rehabilitation of obese students and low level of physical fitness [6]. The author applies differentiated classes for improving aerobics and taking into account the phases of the OMC. There are number of scientific studies that address the issues of building a training process for athletes based on the ability to work in different periods (phases) of specific biological cycle. Fundamental works are considered those $[17,19,25]$, in which the functional status of athletes was studied during specific biological cycle.

The authors [26] considered the connection of the psycho-physiological state and the manifestation of highspeed abilities of high-grade water polo players. The

(C) Petrenko N.V., Petrenko O.P., Romanova V.B.,

Ostapenko V.V., 2017

doi:10.15561/18189172.2017.0605 biological cycle of hormonal changes in their organism was taken into account. Another study [24] examined the effect of the training process of high-skilled athletes (judo) on the psychophysiological state of athletes in various phases of the OMC.

Studies by other scholars [18, 23] also confirmed the need to take into account the biological cycle of women during the training of qualified athletes [14]. An analysis of such studies indicates their relevance. An analysis of scientific papers shown that most studies devoted to questions that examine the effects of various kinds of stress on the body of women athletes of high qualification.

To a lesser extent is studied the question of building a health-training process for girls, especially during specific biological cycle. For athletes, there are certain conditions for performing any physical activity in the adverse periods of the ovarian-menstrual cycle. For students, such conditions require some adaptation. Students feel more significant functional and psycho-physiological stress, which affects their mental and physical ability to work $[8,10,13]$.

The results of many studies indicate that hormonal changes in OMC reflected in the mental and functional state of women. They are also displayed at the level of their special ability to work [20, 22].

Despite a significant number of works [23, 27, 29] during conducting classes with students do not take into account the peculiarities of the biological function of their organism.

Hypothesis. It is assumed that taking into account the peculiarities of the female body (phases of the ovarianmenstrual cycle) in the process of health-training sessions will contribute to the improvement of the functional state 
of the students and the growth of their capacity for work.

The aim of the work is scientifically substantiate the application of rational program of health-training sessions in the educational process of physical education of students in different phases of the ovarian-menstrual cycle.

Materials and methods.

Participants: In study took part 127 students aged 17-19 years old of Sumy State University. All students belonged to the main medical group (not having health abnormalities) and were divided into experimental and control groups. All students agreed to participate in the experiment.

Organization of research. The study was conducted between September 2015 and January 2017. At the beginning of the study was conducted: questionnaires, analysis of the functional state of students. The level of their physical capacity is also determined. During the testing, we were guided by the recommendations of leading specialists in the field of physical education [11]. The results were recorded in general protocol and subject to statistical processing.

From the indicators of functioning of the cardiovascular system were determined: the frequency of heart rate (heart rate, beats per min. ${ }^{1}$ ), blood pressure - systolic (BPS, mm $\mathrm{Hg}$ ) and diastolic (BPD, mm Hg) by Korotkov method. The Vital capacity $(\mathrm{VC}, \mathrm{ml}$ ) was determined using the spirometers of the computer complex NS-psychotest. The students had to complete three attempts. The best attempt was to set off. To determine physical performance was used Harvard step-test [11].

To determine the phases of the OMC was used the calendar method. For this, the next stage of ovulation was determined by measuring basal body temperature. In our studies, body temperature was measured in the oral cavity, under the tongue with a closed mouth (sublingual or oral temperature, Tor). It is recommended to breathe through the nose for maximum reduction of vibrations through inhaled air. Measurement was carried out at the same time of day using the same type of thermometer. For a state of relative rest, the oral temperature was taken as a comfortable level of $36.6 \pm 0.10^{\circ}$. Registration Tor was conducted in the dynamics of all experiments using the digital thermometer firm "Microlife" (Switzerland). The thermometer allows you to measure the temperature of the oral cavity in 1-3 $\mathrm{min}$ (at the sound signal of the thermometer). The measurement accuracy of the instrument is \pm 0.10 . According to the results of observations, a schedule was constructed. Its evaluation was carried out in accordance with the known laws: a day before ovulation, the temperature is slightly reduced; during ovulation the temperature rises by $0,3-0,6$ and remains at this level until the end of the cycle [25]. During the study, the timing of the onset of menstruation and its duration were fixed.

Students of the experimental group were engaged in complexes of health-training exercises, which were assigned individually and corresponded to the phase of
OMC. Students of the control group were engaged in the proposed programs of health-training classes without taking into account the phases of the OMC. The loading was carried out taking into account the functional state of the students. Differentiated used and dosed physical exercises from the main means of health fitness (fitbol aerobics, pilates, stretching, body-art, mind-body).

Statistical analysis: For the treatment of the results of the study it was used: descriptive statistics, sampling method, the criterion of consistency Shapiro-Wilky, Student's criterion and dispersion analysis [4]. The main statistical characteristics of the sample were determined: the arithmetic mean of the sample $(\bar{x})$; standard deviation $(\mathrm{S})$; representative error $(\mathrm{m})$. The reliability level was set at $\mathrm{P}=0,95$ (level of significance $\mathrm{p}=0,05$ ). Some results were obtained at higher levels of significance $\mathrm{p}=0,01$ and $\mathrm{p}=0,001$. In conducting complex pedagogical and biological studies with the participation of students, the Ukrainian legislation on health protection, the Helsinki Declaration of 2000, and the directive No. 86/609 of the European Society regarding the participation of people in medical biology research were observed.

\section{Results.}

It was found that the formation and course of the menstrual cycle is in most students within the limits of the physiological norm. The regularity of the cycle lasts from 21 to 27 days noted by $69 \%$ of the respondents. In $18 \%$ of girls the cycle is not regular. $14 \%$ of students do not control the duration of the cycle. The evaluation of the duration of the menstrual cycle revealed a higher proportion of shorter, prolonged and overly prolonged menstrual cycles in $57 \%$ of students. In $43 \%$ of students the structure of the duration of the menstrual cycle was more favorable.

An important informative indicator is the presence and intensity of a painful sensation before and during the lunar period $[3,7,14]$. An analysis of the survey of students for the presence of pain in the middle of the menstrual cycle showed that in general, they were noted by $47 \%$ of students. In $37 \%$ of the pain arose periodically. Regular pain sensation appeared in $15.2 \%$ of students. At the same time, students note the restrictions on physical activity, or generally avoid exercises.

The students' state of health before the occurrence of menstruation is characterized by the following: the presence of headaches is observed in $23 \%$; $44 \%$ of students increase fatigue; $33 \%$ of students report increasing irritability. Ovulatory, premenstrual, and menstrual days are considered days of biological stress [25, 27, 28].

The obtained data indicate that during the planning of practical classes on the physical education of students, it is imperative to take into account the phases of the OMC. One of the most promising areas in the physical education of students can be the development and implementation of health fitness techniques: regulated physical activity in accordance with the periods of the health-training process of occupations. During conducting classes we must take into account the phases of the ovarian-menstrual cycle. 
In the least favorable phases (premenstrual, ovulatory, menstrual) the volume and intensity of the load decreased. Classes on the proposed methods corresponded to the periods of the annual cycle of training [14, 16, 21]. This approach during the construction of health training sessions contributed to a more rational distribution of loads of different orientations and better adaptation of the body of students to training loads.

In order to determine the functional state of students studied the state of the cardiovascular and respiratory systems. The obtained data are one of the main indicators of functional capabilities and adaptation of the body to physical activity. The average student heart rate was $74,20 \pm 0,29$ beats per min. ${ }^{-1}$. This is somewhat higher than the norm and indicates signs of tense work of the cardiovascular system. Observations show that there is a direct relationship between pulse and physical activity [1, 29]. An analysis of the cardiovascular system performance at the end of the study showed that the mean heart rate of the students of the experimental group in a resting state was from $66,23 \pm 5,01$ beats per min. ${ }^{-1}$ to $68,26 \pm 2,27$ beats per min. ${ }^{-1}$. These indicates compliance with the norm. All these contributes to the purposeful use of the selected means and methods to improve the overall level of physical fitness and functional capacity of the body of students.

To determine the functionality of external respiration, we studied the indicators of the vital capacity (VC). We used the spirometry method. The obtained data indicate that the respiratory function of the thoracic cells of the students corresponds to the average functional level $(3,401 \pm 0,30 \mathrm{ml} / \mathrm{kg})$.

The decrease in the level of general physical activity is observed during the training of the majority of students $[2,12,15,30]$. It should be noted that performance varies in different phases of the biological cycle $[3,7]$. At the beginning of the study of students' physical working capacity it was found that their physical capacity meets the low level. The results of the study of physical working capacity in students of the experimental group changed from $53,2 \pm 0,15$ up to $68,04 \pm 2,48$ standard units $(p<0,001)$. The indices of Harvard step-test in the control group improved from a low level of $51,06 \pm 0,18$ up to $58,18 \pm 2,30$ standard units $(\mathrm{p}<0,05)$. The data of the Student $\mathrm{t}$-criterion is reliably $(\mathrm{p}<0,001)$ confirm a significant increase among the results of the students of the experimental group. To a lesser extent was recorded the growth of these rates in the control group of students. The smallest values of the indices of Harvard step-test are recorded in the ovulatory (III) and menstrual (I) phases. The highest values are recorded in the postmenstrual (II) and postovulatory (IV) phases of the OMC. It was found that physical working capacity in the students of both groups changed wavelike throughout the menstrual cycle.

The construction of a health-training process in accordance with the menstrual cycle is necessary to ensure proper alternation of work and rest. The actions of the main loads on the body of students were planned by us in accordance with the phases of the OMC. This contributed to the rational use of the internal capabilities of the body to achieve optimal effect in the transfer of loads and provided the necessary match between the processes of fatigue and recovery $[16,23,26]$. At the beginning of the pedagogical study, students were encouraged to learn how to identify and record the phases of the OMC. Students learned to assess their condition and body reactions to different loads. The girls conducted a "well-being diary".

On the basis of the data we have developed a table in which the characteristics of the phases of the OMC and recommended training load for the annual mesocycle are given (Table 1).

Consideration in the phases of the ovarian-menstrual cycle of indicators of the functional state, changes in well-being and working capacity give an opportunity: planning loads in the training process; adjust the volume and intensity of loads.

The loadings according to our program are recommended to build by the following ways: in the menstrual phase - the development of flexibility (moderate load); in the postmenstrual phase - development of coordination, overall endurance; in ovulatory - speed development; in postovulatory - development of special endurance; in premenstrual - the development of force, flexibility. It should be noted that the functional state of students of the experimental group significantly changed during the $\mathrm{OMC}(\mathrm{p}<0,05)$. In the postmenstrual and postovulatory phase, a high level of physical working capacity, functional state of the cardiopulmonary system has been registered. It also has a positive effect on body weight correction in the students.

The use of differentiated health fitness in the experimental group and the consideration of the biological cyclicity of the functions of the female body allowed effectively influence the functional characteristics of the students. It positively affected their physical capacity and functional status.

The obtained data of the pedagogical experiment confirmed the effectiveness of the proposed program of health-training classes in most of the studied indicators.

\section{Discussion.}

The development and scientific substantiation of the physical education program classes with students requires solving a number of problems. There must be an appropriate organization and methodological support for the classes. Students need to develop knowledge about healthy lifestyles and personal hygiene. After all, according to the analysis, there are students who do not control their cycle. Such students do not follow their state of health at different phases. The given problem can be solved, if to use organizational-activity approach to the process of employment: to create a certain interrelation of the teacher and students; change the forms of classes and their sequence.

There are studies that provide data on the impact of training sessions with various elements of fitness aerobics on the reproductive system of students [20, 18]. The authors note the need to take into account and regulate 
Table 1. The general structure of the loads according to the periods of annual cycle according to the phases of the ovarian-menstrual cycle

\begin{tabular}{|c|c|c|c|}
\hline Phases of cycle & $\begin{array}{l}\text { Duration (days } \\
\text { from the cycle } \\
\text { start) }\end{array}$ & $\begin{array}{l}\text { Training loadings } \\
\text { Periods of } \\
\text { annual cycle }\end{array}$ & $\begin{array}{l}\text { Characteristics of physical and mental working } \\
\text { capacity } \\
\text { Appropriate development of physical qualities }\end{array}$ \\
\hline $\begin{array}{l}\text { Menstrual } \\
\text { I }\end{array}$ & $\begin{array}{l}3-5 \\
\text { (from } 1 \text { to } 5 \text { ) }\end{array}$ & $\begin{array}{l}\text { Medium (renew } \\
\text { period) }\end{array}$ & $\begin{array}{l}\text { Medium level of physical working capacity: } \\
\text { recommended such exercises as development of } \\
\text { flexibility of temperate force (pilates, mind-body). Low } \\
\text { indices of working capacity }\end{array}$ \\
\hline $\begin{array}{l}\text { Postmenstrual } \\
\text { II }\end{array}$ & $\begin{array}{l}7-9 \\
\text { (from } 6 \text { to } 12 \text { ) }\end{array}$ & $\begin{array}{l}\text { Extensive (main } \\
\text { period) }\end{array}$ & $\begin{array}{l}\text { High level of physical working capacity: development of } \\
\text { general tolerance, force, speed-force abilities, flexibility } \\
\text { (body-art, feetball, stretching). High indices of working } \\
\text { capacity }\end{array}$ \\
\hline $\begin{array}{l}\text { Ovulatory } \\
\text { III }\end{array}$ & $\begin{array}{l}2-4 \\
\text { (from } 13 \text { to } 15 \text { ) }\end{array}$ & $\begin{array}{l}\text { Medium (renew } \\
\text { period) }\end{array}$ & $\begin{array}{l}\text { Low level of physical and mental capability: } \\
\text { recommended the reduction of volume and intensity } \\
\text { of loadings. Development of tolerance (pilates, mind- } \\
\text { body) }\end{array}$ \\
\hline $\begin{array}{l}\text { Postovulatory } \\
\text { IV }\end{array}$ & $\begin{array}{l}7-9 \\
\text { (from } 16 \text { to } 24 \text { ) }\end{array}$ & $\begin{array}{l}\text { Extensive (main } \\
\text { period) }\end{array}$ & $\begin{array}{l}\text { Gradual increase of physical working capacity; } \\
\text { development of aerobic working capacity force, speed } \\
\text { (speed force), (pilates). Mean value of mental working } \\
\text { capacity }\end{array}$ \\
\hline $\begin{array}{l}\text { Premenstrual } \\
\mathrm{V}\end{array}$ & $\begin{array}{l}3-5 \\
\text { (from } 25 \text { to } 28 \text { ) }\end{array}$ & $\begin{array}{l}\text { Short (supporting } \\
\text { period) }\end{array}$ & $\begin{array}{l}\text { Medium level of working capacity: development of } \\
\text { aerobic working capacity, flexibility, force, coordination } \\
\text { abilities (pilates, body-art) }\end{array}$ \\
\hline
\end{tabular}

the intensity of physical activity in different phases of the OMC.

Closer to the discussed problem belong the study of N.V. Sizova [20]. The author shows the changes that arise in the cardiovascular and respiratory systems of students during the pursuit of health-improving aerobics. In this paper, the conclusion is made on the obligatory accounting of the intensity of physical activity in different phases of the cycle.

Currently, there are studies that provide information on the features of conducting lessons for various wellness fitness programs with students. But these studies are fragmentary and need further study. At the present stage, "soft fitness" is a special attention among girls and women: pilates, mind-body, body-art. In the process of health training sessions with students we used the proposed techniques. Our goal was to improve their functional state, physical and mental performance in different phases of the OMC. The loads were planned according to the annual cycle of classes or mesocycles. Our analysis allows us recommend mandatory planning of health training sessions in all mesocycles during the school year. Classes should be conducted taking into account microcycles in accordance with the phases of the OMC: in the favorable phases (postmenstrual and postovulatory) apply the load of the main period; in the unfavorable (menstrual, ovulatory) load of the recovery period; in the premenstrual phase of the load supporting period. According to these phases, the classes use different types of soft fitness. Under favorable conditions - fitbol aerobics, step aerobics, combination of various aerobic species. In unfavorable conditions - pilates, stretching, mind-body and body-art.

The data obtained by us confirm and supplement the research results of other scientists regarding the consideration of the biological function of the female body in the development of programs for physical education $[10,13,20]$.

Comprehensive student surveys show the high effectiveness of the developed organizational and methodological approaches: training by the fitness programs pilates, mind-body, body-art and taking into account the phases of the OMC and the periods of the annual cycle of health-training sessions.

\section{Conclusions}

1. The effectiveness of the proposed methods of training was confirmed by the results of improvement of the main studied parameters in students of the experimental group: an increase in the level of functional status, improvement of physical and mental performance, optimization of OMC (relief of pain, decrease of irritability), increased interest in classes.

2. When developing health-training programs of classes with students it is necessary to consider the following: the phases of the ovarian-menstrual cycle; periods of the training process.

\section{Conflict of interest:}

The authors state that there is no conflict of interest. 


\section{References}

1. Baevskij RM. Analysis of heart rate variability with usage of various electrocardiographic systems. Vestnik aritmologii. 2001; 24: 65-87. (in Russian)

2. Blejer SN. Physical activity - an important factor in the health and functional status. In: International conference "Modern achievements of sports science", Sankt Petersburg; 1994. P. 117-119. (in Russian)

3. Gurkin IuA. Children and adolescent gynecology. Moscow; 2009. (in Russian)

4. Denisova LV, Khmel'nickaia IV, Kharchenko LA. Measurements and methods of mathematical statistics in physical education and sport. Kiev: Olympic Literature; 2008. (in Russian)

5. Diukov VM, Skurikhina NV. High school of a healthy lifestyle. Improvement of health-saving and health-forming activity of higher education institutions. LAP LAMBERT Academic Publishing - Saarbrücken; 2013. (in Russian)

6. Zakharova AN, D'iakova EIu. Development of methods and organization of physical culture for students with diseases of various body systems. In: Interregional scientific-practical conference "Physical culture and sport at the present stage: problems, searches, solutions”. Tomsk; 2012. P. 158-162. (in Russian)

7. Ioffe LA. Peculiarities of puberty in urban and rural teenage girls. Gigiena i sanitariia, 2003;1:53-54. (in Russian)

8. Kenioua Mouloud, Boumasjed Abd Elkader. Sport and mental health level among university students. Physical education of students, 2016; 20(3): 39-42. doi:10.15561/20755279.2016.0305

9. Kolumbet AN, Dudorova LYu. Correction of physical education program for technical higher educational establishment girl-students on the base of their health indicators. Physical education of students, 2016; 20(6): 1825. doi:10.15561/20755279.2016.0602

10.Kopotchinskaya J.V. Research of indexes of bodily condition of students, having surplus mass of body, on extent of phases of ovarian-menstrual cycle. Physical education of students, 2012;1:51-55.

11.Krucevich TIu, Vorobjov MI, Bezverkhnia GV. Control in physical development of children, adolescents and young people. Kiev: Olympic Literature; 2011. (in Ukrainian)

12.Kudryavtsev MD, Kopylov YuA, Kuzmin VA, Ionova OM, Yermakova TS. Personality oriented system of strengthening of students' physical, psychic and social-moral health. Physical education of students, 2016; 20(3): 43-52. doi:10.15561/20755279.2016.0308

13.Martiniuk O, Pechena V, Kravchenko K. Analysis of various methods for assessing the level of physical health of student youth. Fizichna kul'tura, sport ta zdorov'ia nacii, 2014;1:183-189. (in Ukrainian)

14.Mulik V. Modern aspects of the construction of the training process of athletes. Slobozhans'kij naukovo-sportivnij visnik, 2016;5(55):57-62. doi:10.15391/snsv.2016-5.010 (in Ukrainian)

15.Petrenko NV, Loza TA. Model of recreational and training sessions based on the use of funds aqua professionally applied in the preparation of students of economics. Physical education of students, 2014; 18(4): 32-36. doi:10.6084/ m9.figshare.974481

16.Petrenko NV. Optimization of physical and mental capacity of students of economic specialties by means of aquaphthesis. Cand. Diss. Kiev; 2015. (in Ukrainian)

17.Pokholenchuk IuT, Svechnikova NV. Modern women's sports. Kiev: Health; 1987. (in Russian)
18.Prudnikova MS, Mulik VV. Influence of physical loads on the functional state and personal qualities of young bicyclists 12-15 years in the period of formation of the OMC. Slobozhans'kij naukovo-sportivnij visnik, 2009;3:164-167. (in Russian)

19.Radzievskij AR, Loza TA, Radzievskij PA. Anatomicophysiological features of the female body. Kiev; 1975. (in Russian)

20.Sizova NV. Differentiated methods of practicing health aerobics in the process of physical education of students of a technical university. Cand. Diss. Smolensk; 2007. (in Russian)

21.Skurikhina NV, Kudryavtsev MD, Kuzmin VA, Iermakov S S. Fitness yoga as modern technology of special health groups' girl students' psycho-physical condition and psychosocial health strengthening. Physical education of students, 2016; 20(2): 24-31. doi:10.15561/20755279.2016.0204

22.Strizhkova TIu. The use of neurobiomanagement in the optimization of the functional state of gymnasts, taking into account the phases of the ovarian-menstrual cycle. Cand. Diss. Chelyabinsk; 2012. (in Russian)

23.Fomin SK, Pivovarova VI. Management of the training process of students with specific biological characteristics of their body. In: Problems of physical education of students. Baku; 1981. P. 56. (in Russian)

24.Chistiakova MO. Construction of a training process aimed at increasing the special ability of athletes of high qualification specialized in judo. Cand. Diss. Kiev; 2014. (in Ukrainian)

25. Shakhlina LG. Medical and biological bases of sports training of women. Kiev: Scientific opinion; 2001. (in Russian)

26.Shakhlina LIa-G, Evpak NA. Interrelation of the psychophysiological state and special working capacity of qualified athletes specializing in water polo. Sportivna medicina $i$ fizichna reabilitaciia, 2015;1-2: 59-63. (in Russian)

27.Shchedrina EV. Physiological evaluation of the effect of physical training and olfactory influences on the functional state of the student body. Cand. Diss. Astrakhan; 2015. (in Russian)

28.Jagiello W, Sawczyn S, Jagiello M. The subjective profile of positive health and survival abilities in women differing as to physical activity. Archives of Budo. 2012;8(4):219-24.

29.Pryimakov O, Iermakov S, Kolenkov O, Samokish I, Juchno J. Monitoring of functional fitness of combat athletes during the precompetitive preparation stage. Journal of Physical Education and Sport, 2016;16(2), 551-561. doi:10.7752/ jpes.2016.02087

30.Ward P. The role of content knowledge in conceptions of teaching effectiveness in physical education. Res $Q$ Exerc Sport, 2013;84:431-440.

31.Sawczyn S, Mishchenko V, Moska W, Sawczyn M, Jagiello M, Kuehne T, et al. Strength and aerobic training in overweight females in Gdansk, Poland. Open Medicine. 2015;10(1):152-62.

32.Wolyniec W, Ratkowski W, Urbanski R, Bartoszewicz M, Wolyniec Z, Siluk D, et al. Urinary kim-1 but not urinary ngal is increased after short maximal exercise. Nephrology Dialysis Transplantation. 2016;31:149-149. 


\section{Information about the authors:}

Petrenko N.V.; http://orcid.org/0000-0002-8563-8606; n.petrenko@uabs.sumdu.edu.ua; Sumy State University; UI. RimskyKorsakov, 2, Sumi, 40001, Ukraine.

Petrenko O.P.; http://orcid.org/0000-0002-7988-1773; akrobatka_sumy@mail.ru; Sumy State University; Ul. Rimsky-Korsakov, 2, Sumi, 40001, Ukraine.

Romanova V.B.; http://orcid.org/0000-0002-5717-1826; Romanova1603@gmail.com; Sumy State University; Ul. Rimsky-Korsakov, 2, Sumi, 40001, Ukraine.

Ostapenko V.V.; http://orcid.org/0000-0003-1771-3210; v.ostapenko@uabs.sumdu.edu.ua; Sumy State University; UI. RimskyKorsakov, 2, Sumi, 40001, Ukraine.

Cite this article as: Petrenko NV, Petrenko OP, Romanova VB, Ostapenko VV. Analysis of the functional state of students in the process of healthy training exercises in different phases of the ovarian-menstrual cycle. Pedagogics, psychology, medicalbiological problems of physical training and sports, 2017;21(6):285-290. doi:10.15561/18189172.2017.0605

The electronic version of this article is the complete one and can be found online at: http://www.sportpedagogy.org.ua/index.php/PPS/issue/archive

This is an Open Access article distributed under the terms of the Creative Commons Attribution License, which permits unrestricted use, distribution, and reproduction in any medium, provided the original work is properly cited (http://creativecommons.org/licenses/by/4.0/deed.en).

Received: 08.10.2017

Accepted: 25.10.2017; Published: 05.11.2017 